Robert G. Ousterhout

Professor Department of the History of Art

Director of the Centre for Ancient Studies

University of Pennsylvania

Philadelphia, USA

ORCID 0000-0002-4323-2296

\title{
EASTERN MEDIEVAL ARCHITECTURE. RUSSIA
}

We publish in this issue the continuation of the translation of the new book of the outstanding historian of the architecture of Byzantium professor of Penn University (USA) and professor honoris causa of the Moscow Institute for Architecture (State academy) "Eastern Medieval Architecture. The Building Traditions of Byzantium and Neibouring Lands (Oxford University Press, 2019). This part of the book of the scholar is devoted to the development of the Byzantine tradition in Russian postrenaissance architecture. The description of Robert Ousterhaut's scholarly biography and his impact to the study of the history of architecture was published in the previous issue of this magazine in the article of Dmitry Shvidkovsky "Ousterhaut and the Byzantium".

Summary: It is impossible to overestimate the role of professor Robert Ousterhaut in the studies of the history of Byzantine art. At the present day he is the leader in the world studies of the architecture of Byzantium, the real heir of the great Rihard Krauthaimer and Slobodan Curcic, whom he had left behind in his works. His books are known very well in Russia. In his study of Russian architecture of the Middle Ages, the author analyses the artistic image and the design characteristics of church architecture. The author highlights the distinctive features of the largest centres of Moscow, Novgorod, Pskov, Chernigov, and other cities. Much attention is paid to the influence of Italian architecture on the development of Russian church construction, which is associated with the participation of Italian architects in the construction of the main churches in Moscow. The outstanding cathedrals of the Moscow Kremlin - the Assumption, the Annunciation, and the Archangel Michael cathedrals, created with the participation of Italian architects, are considered in detail.

Russian history and Russian architecture take a very different course. Much of Russia was destabilized in the thirteenth century by the invasion of the Mongols, with the notable exceptions of Novgorod and Pskov, where medieval churches survive from the twelfth century onward. In Novgorod, churches like the St. Theodore Stratelates (1360) or the Church of the Transfiguration of the Savior on Elijah Street (1374) have simple nine-bayed plans, marked by pilasters on the façades, with steeply pitched roofs rising to a single dome (Fig. 1) ${ }^{1}$. Distinctive

1. For Russian architecture, see H. Faensen and V. Ivanov, Early Russian Architecture (London, 1975); Brumfield, A History
The author considers St. Basil's Cathedral, built by Ivan IV (the Terrible) in memory of his victory near Kazan in 1552, to be the most impressive building of this period. The church has a unique composition. It consists of nine adjoining chapels.

In his research, the author also highlights one of the unresolved issues in the development of Russian architecture - the appearance of a characteristic onion dome. One of the assumptions put forward by the author is that the domes reflect the shape of the canopy over the Tomb of Christ. The influence of Islamic forms introduced into Russian architecture after the triumphant victory of the Russian troops in the Battle of Kazan, which brought significant territories of Mongolia under Russian control, is the author's another hypothesis. The author cannot single out a priority version but rightly believes that whatever the initial meaning of domed forms in Russian architecture was, they quickly became popular and acquired their symbolism.

Keywords: Russian architecture, Eastern Medieval Architecture, history of architecture.

is the use of quadrant arches on the corner façade bays, as had been employed earlier at the Piatnitsa Church in Chernigov (see Fig. 12). In the Novgorod churches, the quadrant arches are multiplied to decorative effect. As with most of the late buildings in the area, both are roughly built, with plastered exteriors.

As Russia recovered from the Mongol invasions, Muscovy developed its own distinctive architecture, first seen perhaps in the cathedrals of Zvenigorod, near Moscow, dedicated to the Dormition (ca.

of Russian Architecture; augmented by the many insights in Shvidkovsky, Russian Architecture. 


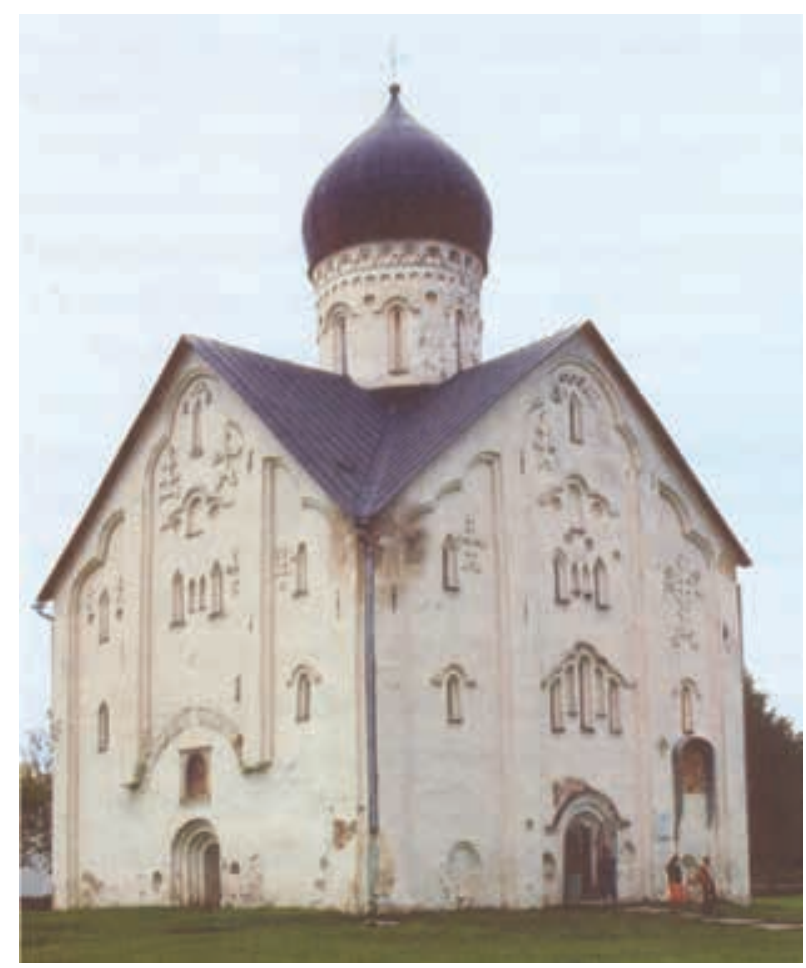

IIl. 1. Novgorod, Church of the Transfiguration of the Savior on Elijah Street, view from the southeast (author)

1396-98, now much altered) and the Nativity of the Virgin in the Storozhevsky Monastery of St. Savva (ca. 1405-8) (Fig. 2). [NB: Unlike Byzantium, where a single church per district or city had the rank of cathedral, in Russia, multiple churches within the same area could have this rank.] Both have simple, nine-bayed plans with a central dome- the standard plan through out Russia, ultimately derived from the Byzantine cross-in-square type. In many ways, the Zvenigorod churches (and, indeed, their nowlost counterparts in Moscow) hark back to the model of Vladimir from before the Mongol Conquest, with tall proportions and construction of white limestone. Façade bays are topped by decorative arches, or zakomary, rising above pilasters or colonnettes. Decorative bands of sculpture enliven the façades, and the portals have stepped jambs and archivolts, with ogival arches. The zakomary of the Dormition Church must have also had ogival arches, as are preserved at the Nativity Church. In addition to those of the façade, there is a second zone set diagonally above the corner bays and a third zone framing the dome drum. The decorative aspects of the zakomary are enhanced by a loosening relationship between interior and exterior, as the pilasters do not always correspond to the structural divisions of the interior. These details appear in the oldest surviving Moscow church, the Cathedral of the Savior in the

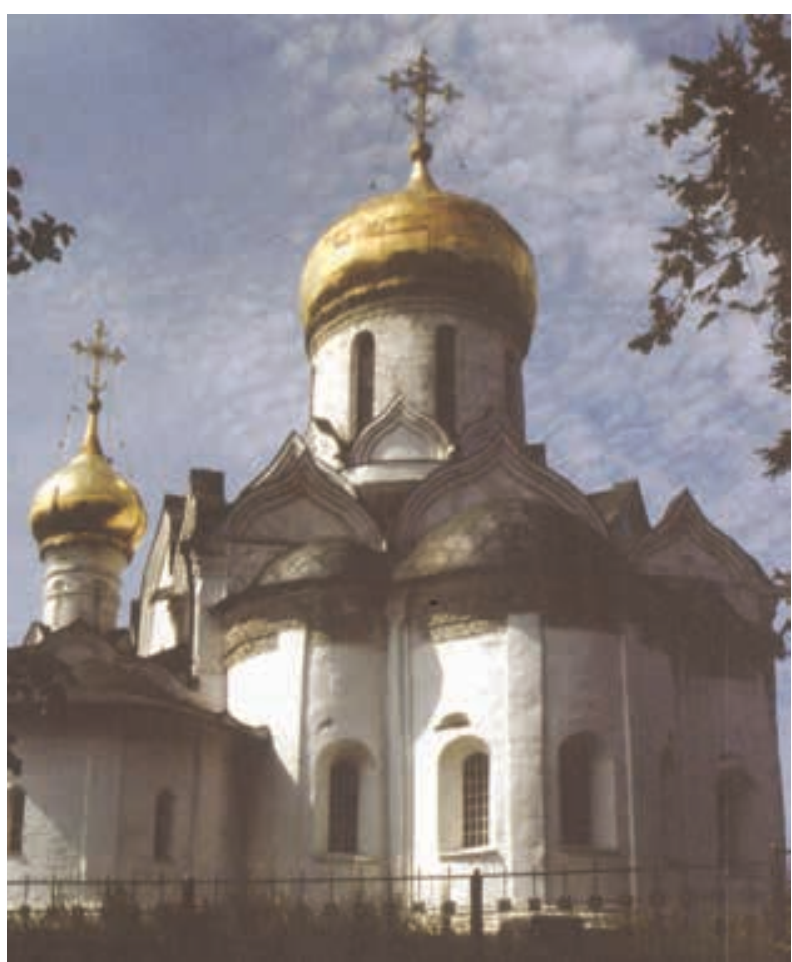

IIl. 2. Zvenigorod, Cathedral of the Nativity of the Virgin in the Storozhevsky Monastery of St. Savva (courtesy of Moscow Architectural Institute Scientific Library)

Andronikov Monastery, built in the 1420 s, which increases the complexity of the decorative arcading, as it steps up gradually to the base of the dome.

The beginnings of Moscow are usually traced to its first textual reference in 1147 , although the settlement must have been older. In 1156, a wooden fortress rose on the high ground at the confluence of the Moscow and smaller Neglinnaia Rivers, where the Kremlin now stands (Figs. 3 and 4). The name Kremlin means "citadel," but like the Acropolis in Athens, it became a site-specific toponym. Moscow's early history is marked by clashes with the Mongols and with feuding Russian principalities; for much

of its early history, it was little more than a trading outpost in the vast forests of Russia. By the fourteenth century, Moscow began to emerge as the central power, notably under Ivan I, who took control in 1325. In the same year, the patriarch Peter made Moscow his unofficial residence, thus marking the beginnings of the consolidation of church and state. The first stone church was built shortly thereafter, the Cathedral of the Dormition (subsequently rebuilt), significantly adopting the dedication of the Cathedral of Vladimir, the spiritual centre of Russia. Facing continued confrontations with the Mongols, the fortifications were rebuilt in limestone in 1367, more or less along the lines of the current triangu- 


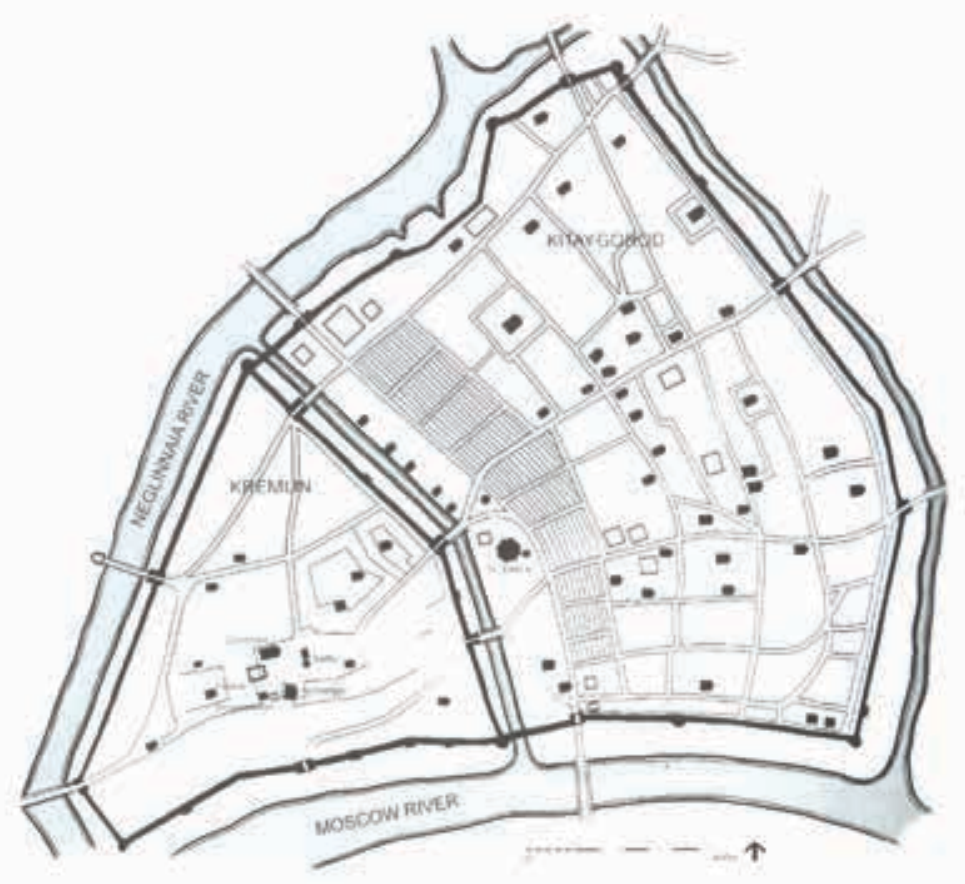

IIl. 3. Moscow, Historic plan of the Kremlin and Kitay-Gorod (author, after Moscow Institute of Architecture Scientific Collection)

lar enclosure, extending approximately 2 kilometres in length. Because traditional Russian architecture was ephemeral, built of wood and prone to fires, the appearance of the Kremlin and the city around it difficult to envision before the fifteenth century.

By the late fifteenth century, a new architectural impetus arrived from Italy, in the form of imported Italian architects. The period of Ivan III (r. 1462-1505) is particularly important, followed by that of his son, Vasili III (r. 1505-33). In 1472, Ivan married Zoe (renamed Sophia) Palaiologina, niece of the last Byzantine emperor and claimant to the Byzantine throne ${ }^{2}$. With the collapse of the Byzantine Empire, she had fled to the papal court in Rome, where she came under the protection of Cardinal Bessarion, who subsequently arranged her marriage to Ivan. Through Bessarion, Sophia was associated with the Greek and Italian intellectual circles of northern Italy and thus arrived in Moscow with both Italian Renaissance and Byzantine imperial baggage. Shortly thereafter, Italian architects appear prominently in the historical record ${ }^{3}$.

The first major project was the rebuilding of the Cathedral of the Dormition in the Kremlin, 1475-79, under the direction of Rodolfo Fioravanti, nicknamed Aristotele (Figs. 5-7). A reconstruction of the original church had been undertaken by Muscovite builders

2. A.-M. Talbot, "Sophia Palaiologina," Oxford Dictionary of Byzantium, $3^{\text {rd }}$ vol. (Oxford, 1991), 1928.

3. Shvidkovsky, Russian Architecture, 73-104. in 1472, but it collapsed two years later as it neared completion. Masons from Pskov were consulted, but they declined to take on the project, leading Ivan to seek outside expertise. The Bolognese architect Fioravanti was well known in Italy for his engineering skills, and he was a friend of the theorist Filarete. Once he arrived in Russia, he was taken to Vladimir to examine the Cathedral of the Dormition, which his project was intended to imitate and to surpass (see Figs. 8 and 9). He thus combined Romanesque details derived from Vladimir with a simplified twelve-bayed plan, topped by five domes. Fioravanti introduced a modular plan, so that all bays are the same dimensions, with groin vaults set at the same height covering the undomed bays, rising above cylindrical piers. To maintain the modular scheme, coupled chapels flanking the sanctuary were covered by a single dome, and to give it prominence, the central dome was increased in scale, with a diameter larger than the width of the bay it covers.

Rather than a separate narthex, the western three bays, all groin vaulted, are fully integrated into the modular design. On the façades, details are simplified; arcades are identical, the bays marked by pilasters, while the Romanesque forms of the portals and the corbel table frieze recall Vladimir. Fioravanti used a carefully cut limestone ashlar, the stones set with a strong mortar, while the vaulting was constructed of lightweight brick, reinforced with iron ties. 


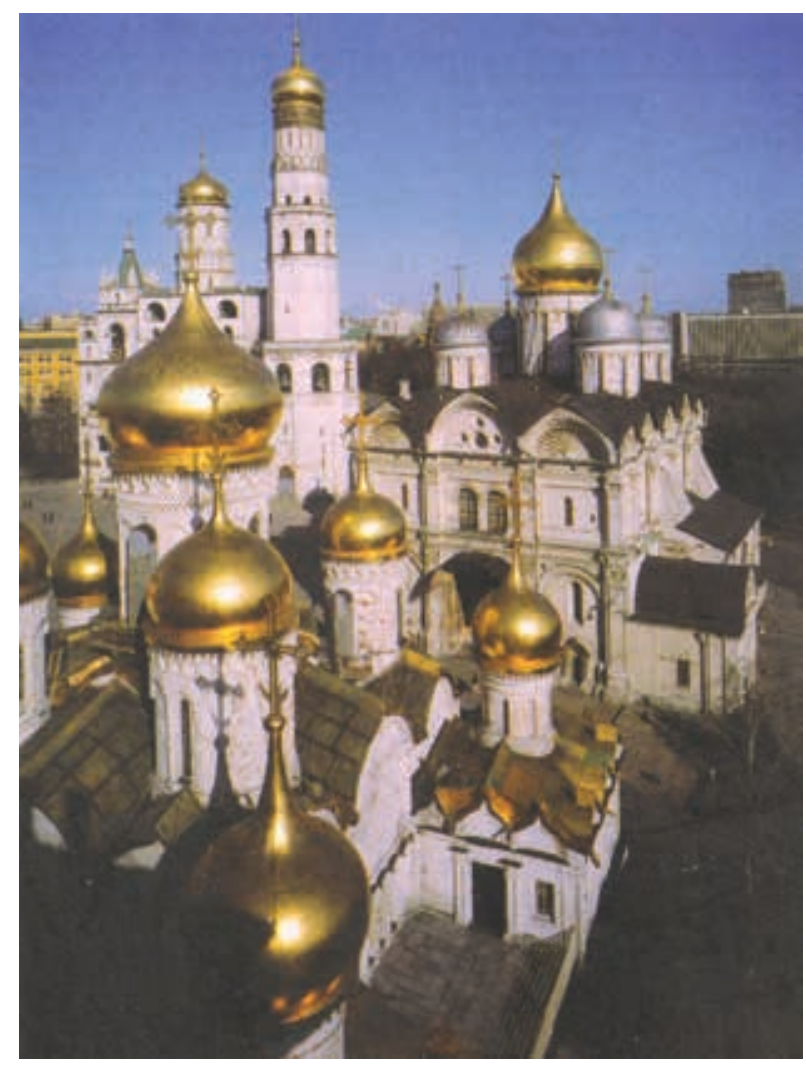

IIl. 4. Moscow, Kremlin, general view looking east, with the Cathedral of the Annunciation in the foreground and the Cathedral of the Archangels and the Bell Tower of Ivan the Great behind it (courtesy of Moscow Architectural Institute Scientific Library)

The lofty interior has the feel of a spacious hall, easily adaptable for imperial ceremony, as it became the coronation church. The gradual raising of the iconostasis in subsequent centuries now blocks the view into the eastern vaults, and although it blends seamlessly with the multiple registers of mural painting, the iconostasis alters the spatial configuration, so that the central dome no longer appears centrally but as the termination of the longitudinal axis of the naos, with the sanctuary invisible behind the screen. In short, the cathedral represents a traditional Russo-Byzantine architectural vocabulary reinterpreted by an Italian Renaissance architect.

Paralleling the introduction of Renaissance architectural ideas was the introduction of Byzantine court ceremonial and ideology. Both seem to have come with the entourage of Sophia Palaiologina. Ivan selected the offspring of Sophia as his heir, rather than the children of his first wife, thus insuring a Byzantine bloodline. Within a few decades, we begin to find references to Moscow as the "Third Rome" and the "Second Constantinople," as Russia assumed the role of political and spiritual successor to Byzantium as the bastion of Orthodoxy. With court ceremonial came court titles, and Ivan III be- gan to use the titles of tsar (derived from Caesar) and imperator (emperor).

Soon after the completion of the Dormition Cathedral, the nearby Cathedral of the Annunciation was rebuilt, 1484-89, to serve as the palace chapel (Figs. 8 and 9). Work was done by architects from Pskov, who had earlier declined to take on the challenge of rebuilding the Dormition Cathedral after its collapse. Their church was considerably smaller and simpler, essentially a nine-bayed church with pier supports, set atop a vaulted substructure to bring it to the level of the residential chambers in the adjoining palace, to the west. It was originally topped by three domes, with two small domes above the chapels flanking the sanctuary, its silhouette enhanced by superimposed gables (kokoshniki) with ogival arches. Through the next century it was expanded, with a covered terrace forming an ambulatory, surmounted by independent domed chapels on the gallery level (1562-64), with two new domes added above the western corners of the naos. In comparison to the Dormition Church, the interior is relatively cramped, limited by the famed iconostasis (painted by Theophanes the Greek, Prokhor of Gorodets, and Andrei Rublev), which closes off the sanctuary and flanking chapels. Despite its rank as cathedral, the church functioned as a private chapel for the devotions of members of the royal family. Stylistically quite distinct, the Annunciation Cathedral represents the continuation of traditional architectural forms, which parallel the Renaissance imports.

The cathedral of the Archangel Michael at the Kremlin, built ca. $1505-9$ by Alevisio Lamberti da Montagnana, a Venetian architect, continues the Renaissance trend begun by Fioravanti (see Fig. 4). The five-domed design follows that of the Dormition Cathedral, but smaller in scale. Its elegant exterior is classicizing, with Corinthian capitals to the pilasters and ornamental half-shells in the zakomary. Similarly, the Great Bell Tower of Ivan III was begun by a Milanese architect known as Bon Fryazin (1505-8), its lower portions resembling a Lombard-style, freestanding campanile although it was subsequently heightened and expanded to house twenty-one bells (see Fig. 4).

Beginning in 1485, the Kremlin was strengthened with new walls of red brick, following the line of the older stone walls, punctuated with projecting towers (Fig. 10). The work is credited to a mixed team of Russian and imported Italian builders, with the latter directing the construction of the towers. With fortification of the residential neighbourhood Kitay-Gorod 


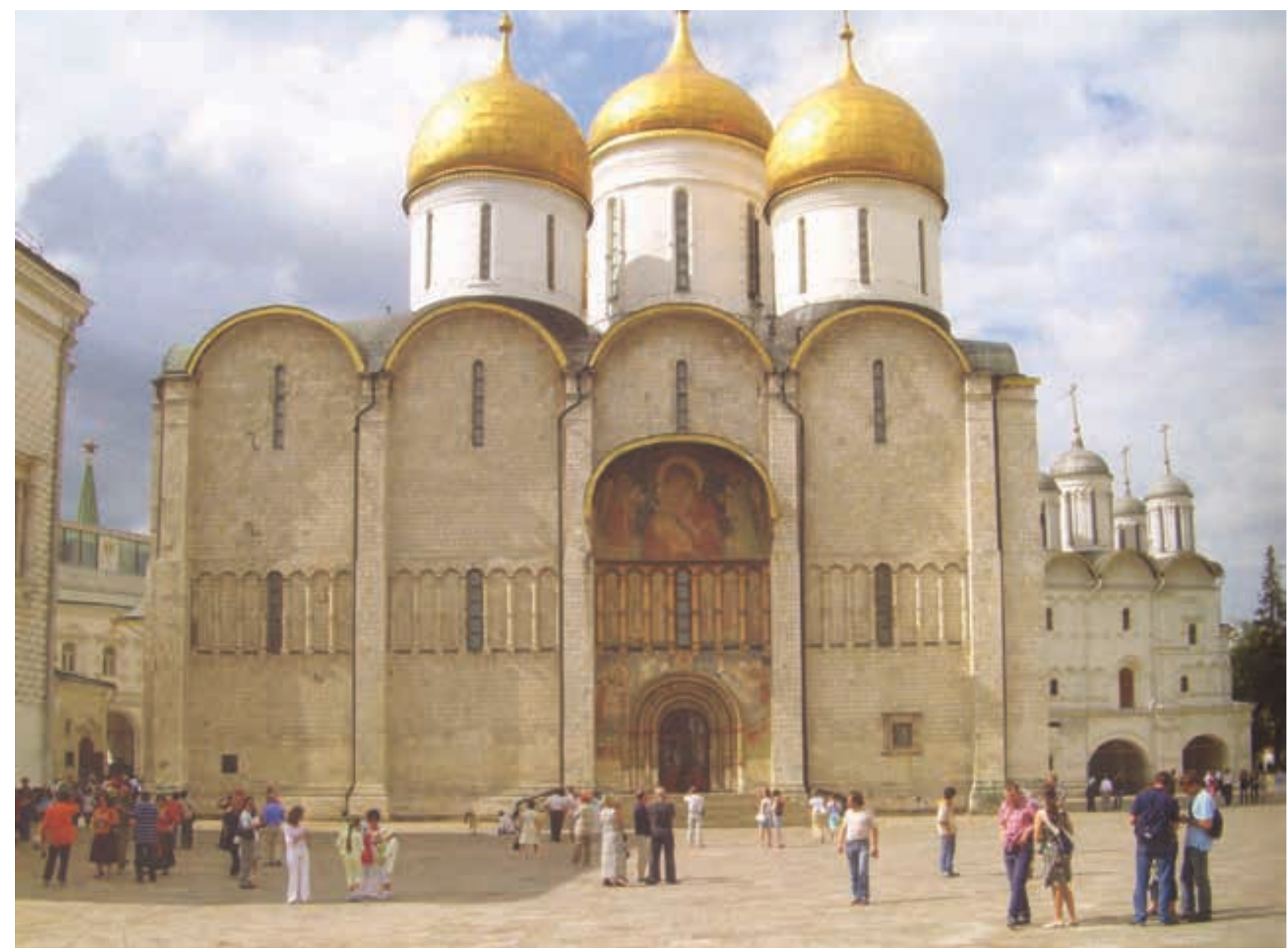

IIl. 5. Moscow, Kremlin, Cathedral of the Assumption, view from the south (author)

to the east, 1536-39, the layout of Moscow began to resemble that of Smederevo in Serbia, with the citadel at the strategic point of a large triangular enclosure, separated internally from the residential area by a moat (see Fig. 3). At the same time, the towers reflect contemporary developments in Italian Renaissance- specifically Lombard-architecture. If we discount the later decorative extensions, the walls of the Kremlin would not look out of place in Milan.

At Kolomenskoe, once an imperial estate overlooking the Moscow River, several churches are preserved, the most important of which is the Church of the Ascension, built after 1528 to commemorate the birth of Ivan IV and dedicated in 1532 (Fig. 11). The plan is without precedent: a square naos expanded with cruciform arms, set on an elevated platform. As the church rises, the upper stage is octagonal, covered by a pyramidal tent roof, all constructed in brick. Kokoshniki appear at the transition to octagon, with zakomary at the base of the steeply pitched roof. The tent roof, or chatior, seen for the first time here, became a prominent feature in the architecture of the period of Ivan, but its origins are obscure. One theory is that the chatior developed out of indige- nous wooden architecture, although no examples are preserved from this early period (compare Fig. 12) ${ }^{4}$. Following this line of thought, the new architectural forms represented by Kolomenskoe stand in sharp contrast to the Italian-built cathedrals of the Kremlin and could thus mark a conservative, nationalistic backlash against the foreign influences.

Recent scholarship has emphasized the Italian Renaissance (and even some Gothic) details of the Church of the Ascension, however, and documentary evidence now indicates that an Italian architect, Pietro Annibale, known in Russian as Petrok Maly, was responsible for its design- the same architect who had directed the construction of the walls of Kitay-Gorod ${ }^{5}$. It clearly demanded a skilled engineer to create the 62-meter-tall building, which required foundations 9 meters deep. All the same, the architect was certainly aware of the visual impact of traditional Russian forms, as the application of kokoshniki and zakomary attests. Should the chatior fall into the same category? Whatever the case, it would appear that an Italian architect was respon-

4. Faensen and Ivanov, Early Russian Architecture, 437-39.

5. Shvidkovsky, Russian Architecture, 111-21. 


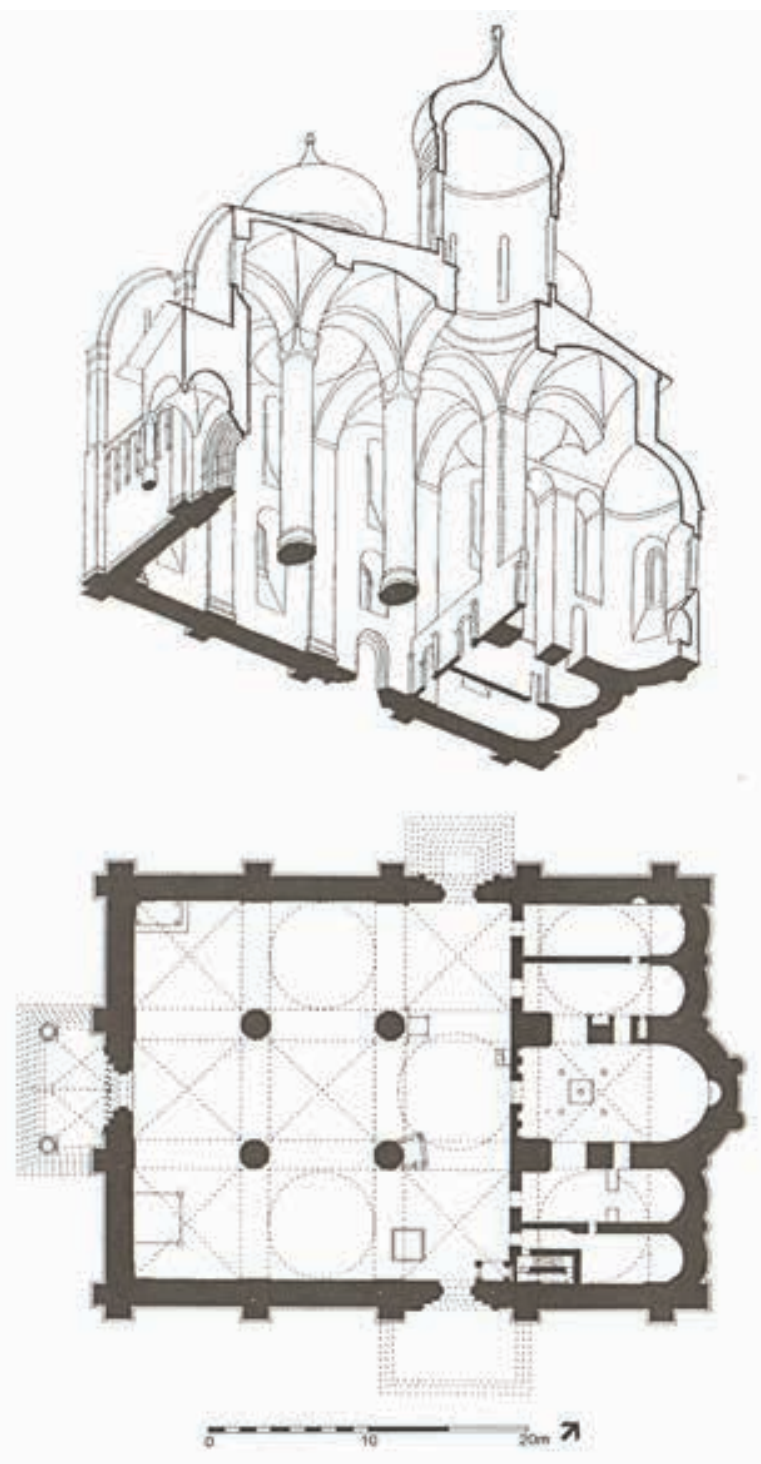

IIl. 6. Moscow, Kremlin, Cathedral of the Assumption, plan and isometric section (redrawn After D. Shvidkovsky, Russian Architecture and the West, 2007)

sible for the introduction of the distinctive form in masonry- one that has come to be interpreted as an indigenous Russian form.

The most iconic of the Moscow churches is also the most unusual. The Cathedral of St. Basil was built by Ivan IV (the Terrible) to commemorate his 1552 victory at Kazan - a critical event in Russian history; the church was completed in 1561 (Fig. 13) ${ }^{6}$. It was originally dedicated to the Intercession of the Virgin, but it gradually became associated with Basil the Blessed, a holy fool whose burial chapel was added at the end of the sixteenth century. The original church actually consisted of nine adjoining chapels raised on an elevated platform. Eight chapels around the perimeter rise to different heights and are topped

6. Shvidkovsky, Russian Architecture, 126-40.

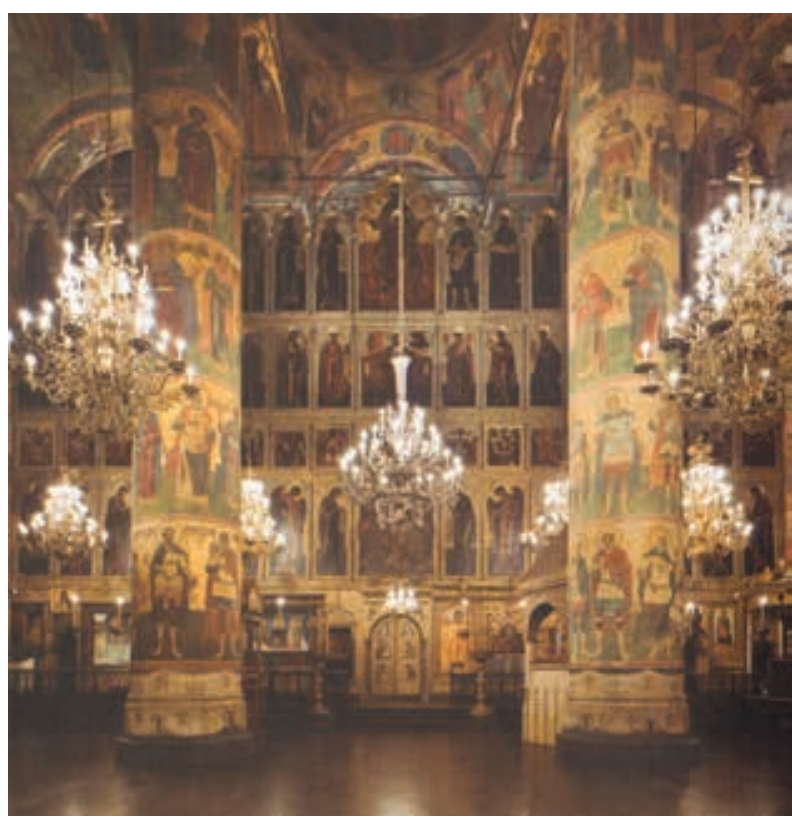

IIl. 7. Moscow, Kremlin, Cathedral of the Assumption, interior, looking east (courtesy of Moscow Architectural Institute Scientific Library)

by picturesquely distinctive onion domes. The central chapel - that of the Virgin - towers above the rest and is covered by a pyramidal tent roof, crowned by a tiny, gilded onion dome. The interior spaces are tall and tower-like, with maximum visual effect devoted to the exterior. The onion domes are in fact hollow, formed by metal sheathing over an armature; on the interior, the chapels terminate in rather modest cloister vaults.

In many ways, St. Basil's resembles a stage set, and it appropriately became the backdrop for the civic and religious ceremonies through which Moscow symbolically expressed its identity. The main western chapel was dedicated to the Entry of Christ into Jerusalem, and this became the focus of a special ceremony on Palm Sunday: conducted by the tzar, the patriarch rode a donkey at the head of a procession that ceremonially recreated Christ's entry into Jerusalem. Through such ceremonies, the church-and subsequently Moscow- became associated with Jerusalem.

One of the lingering questions in the development of Russian architecture is the appearance of the distinctive onion dome: does it have a special meaning or function? Most of the churches just discussed were constructed without them, only to have them added in later remodelings. Those at St Basil's are obviously integral to its inception.

One suggestion is they are functional, diverting snowfall from the roof. Another hypothesis is they reflect the form of the canopy above the Tomb of Christ in the Holy Sepulchre. Perhaps the most 


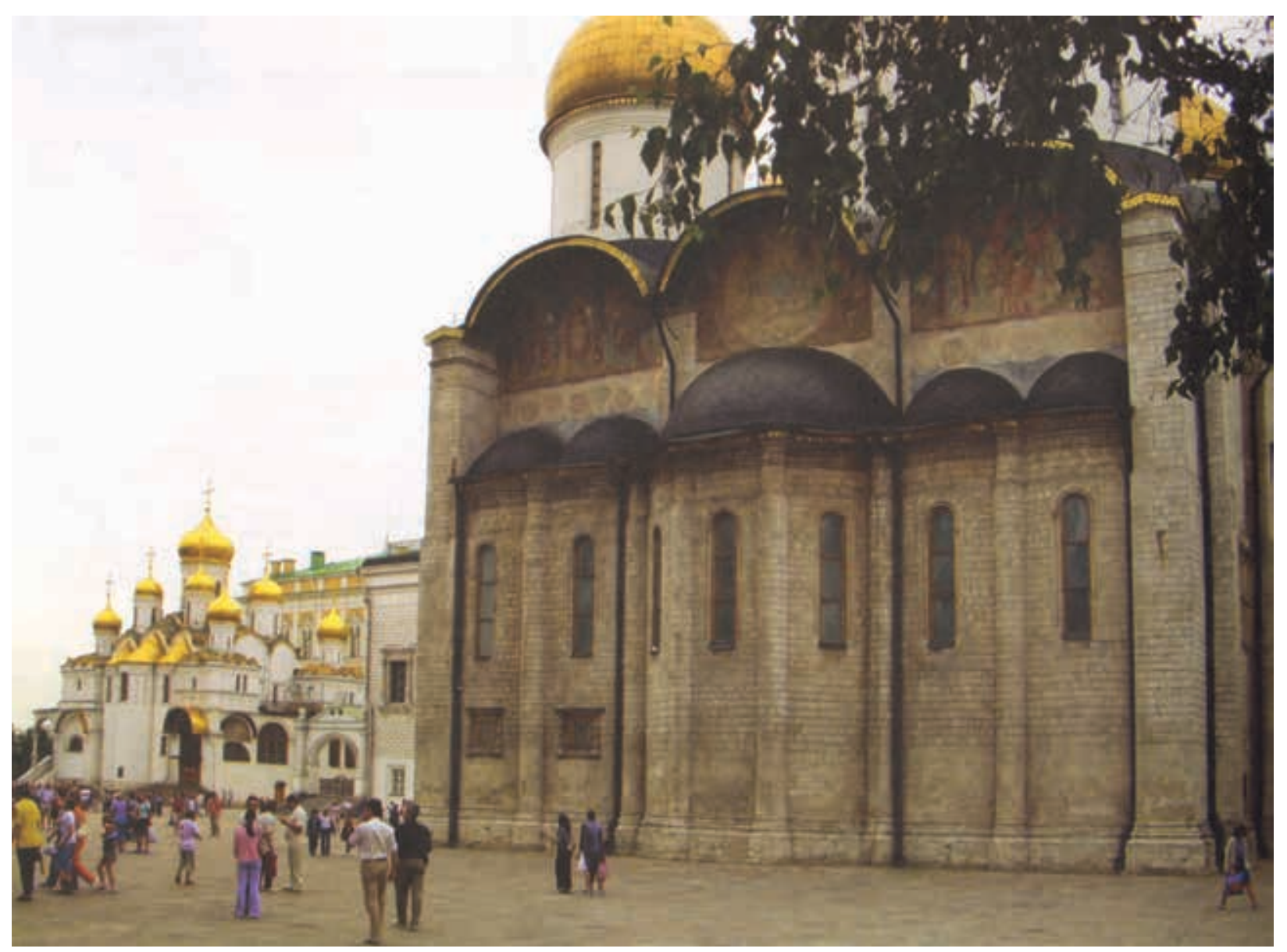

IIl. 8. Moscow, Kremlin, Cathedral of the Assumption, east façade, with the Cathedral of the Annunciation in the distance (author)

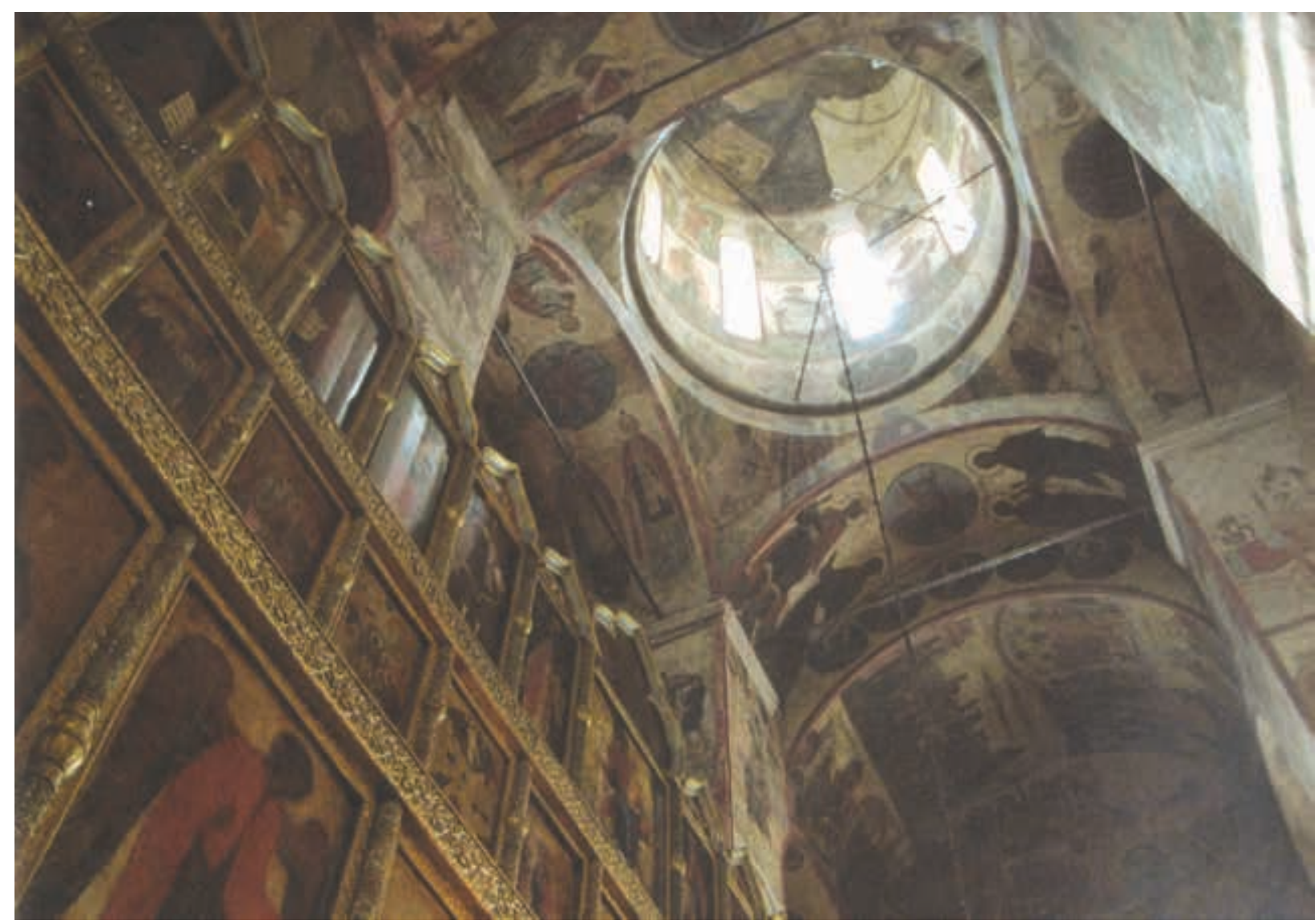

IIl. 9. Moscow, Kremlin, Cathedral of the Annunciation, interior, looking southeast toward the iconostasis (Shakko, Wikimedia Commons) 


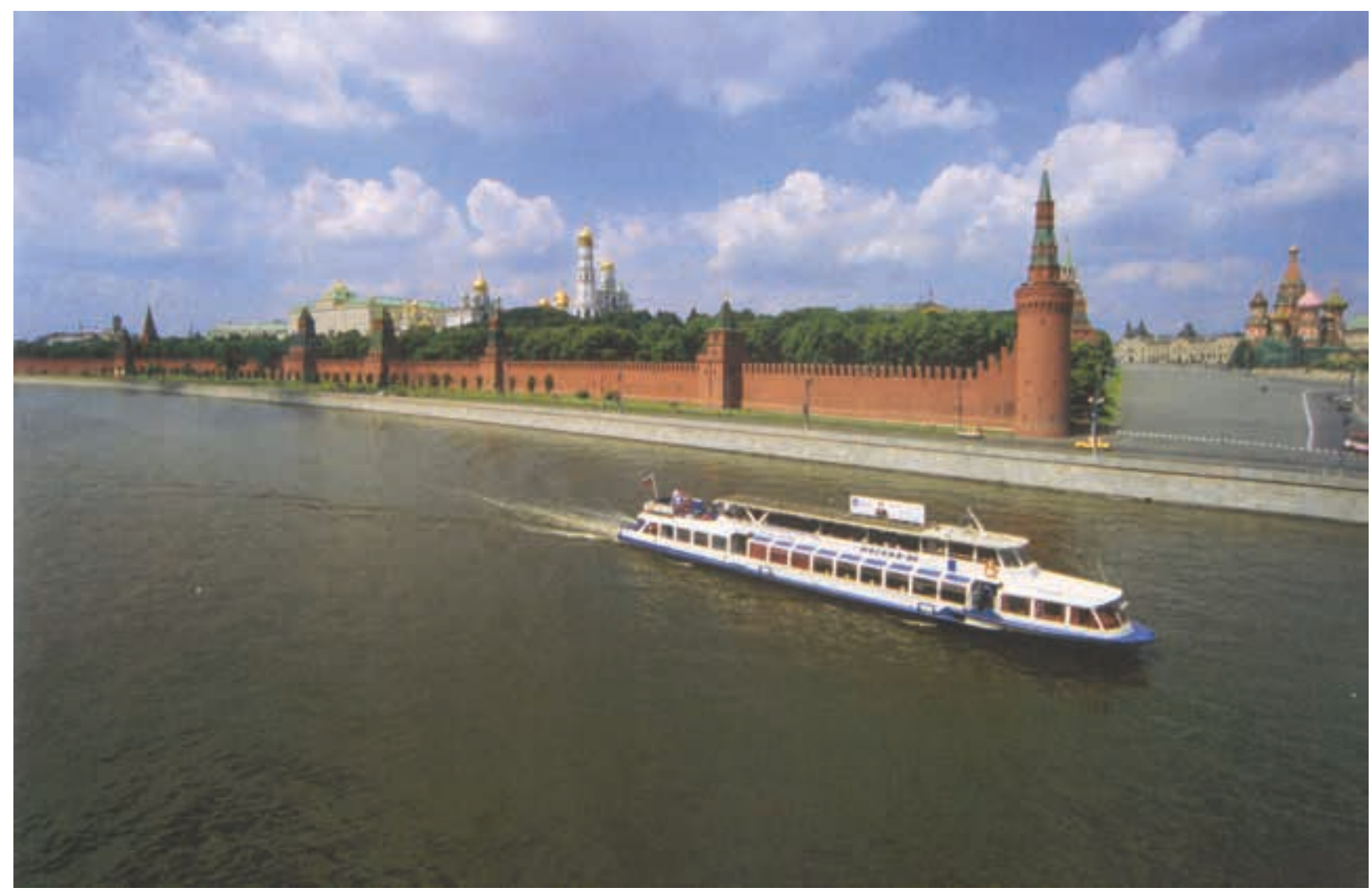

Ill. 10. Moscow, Kremlin, view of the fortifications from the Moscow River (Gerald Carr)

compelling suggestion is an indebtedness to Islamic forms, adopted as a triumphalist motif after the Battle of Kazan, which brought significant Mongol territory under Russian control ${ }^{7}$. Whatever their original meaning, they quickly became popular and took on a symbolism of their own, their shape compared to the flame of a candle, as a beacon of Orthodoxy.

Not all churches in Moscow resemble St. Basil's. The Renaissance rethinking of Byzantine forms at the Dormition Cathedral found a notable following, as, for example, at the Cathedral of the Dormition in the monastery of the Trinity and St. Sergius at Zagorsk (1559-85), which copies its namesake almost exactly, including the modular,

twelve-bayed plan, with five domes and five apses. Built under Ivan IV, the repetition of forms was intended to represent the power and royal associations of the monastery. Constructed almost simultaneously with St. Basil's and by the same patron, the church reflects the stylistic diversity possible in Russian architecture. Another stylistic alternative is provided by the Donskoy Monastery, founded in 1591 on the site where the future tzar Boris Godunov repelled a Tatar attack, aided by the miraculous icon

7. Shvidkovsky, Russian Architecture, 128, with additional notes to works (in Russian) by Brunov, Ilyin, Batalov, Vyachanina, and Bondarenko. of the Virgin of the Don (Fig. 14). The Old Cathedral, constructed in 1591-93, is relatively simple in plan, but its roof is composed of a series of zakomary, organized pyramidally to culminate in an onion dome raised above a tall drum. As in many examples, the dramatic exterior impression contrasts with a relatively conservative interior.

Russia's debt to the Mediterranean past is also evident in the Monastery of the New Jerusalem at Istra, near Moscow, begun in 1656 by Patriarch Nikon (Fig. 15) ${ }^{8}$. A scale copy of the Church of the Holy Sepulchre in Jerusalem, translated into a picturesque Russian vernacular, it appears considerably more spectacular than its prototype. At the same time, the monastery is painstakingly accurate in following the Jerusalem building, based on plans and models. Built to the same scale in plan as the original, it rose considerably taller, with a great conical vault towering above the Rotunda, over 60 meters high. Criticized in his day for his presumption, Nikon's contemporaries viewed his building more as a hijacking of the sacred than as a conceptualization of it.

8. Shvidkovsky, Russian Architecture, 169-73; R. G. Ousterhout "Building the New Jerusalem," in Jerozolima w kulturze europejskiy, eds. P. Paszkiewicza and T. Zadroznego (Warsaw, 1997), 143-54. 


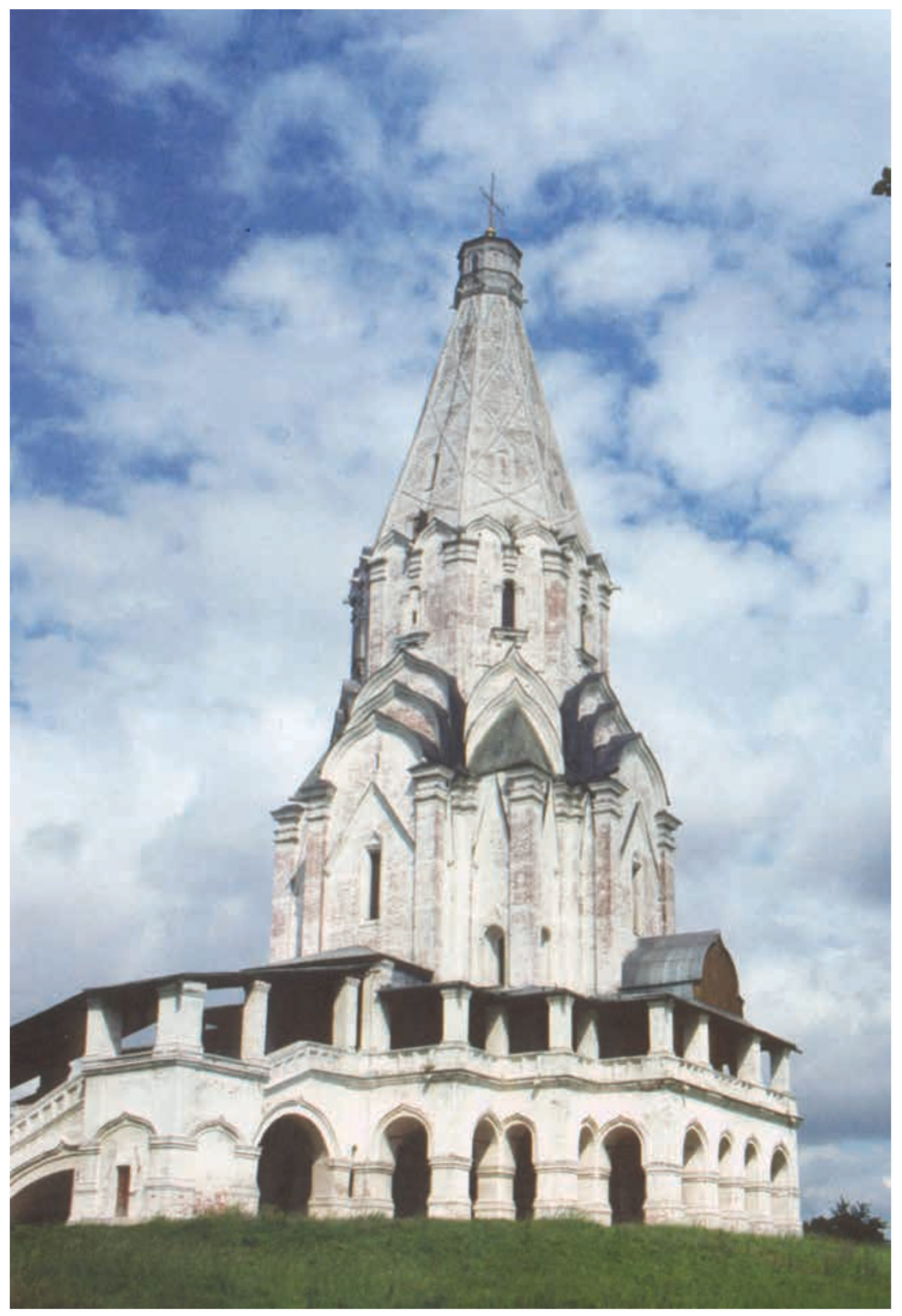

IIl. 11. Kolomenskoe, Church of the Ascension, view from the north (author) 


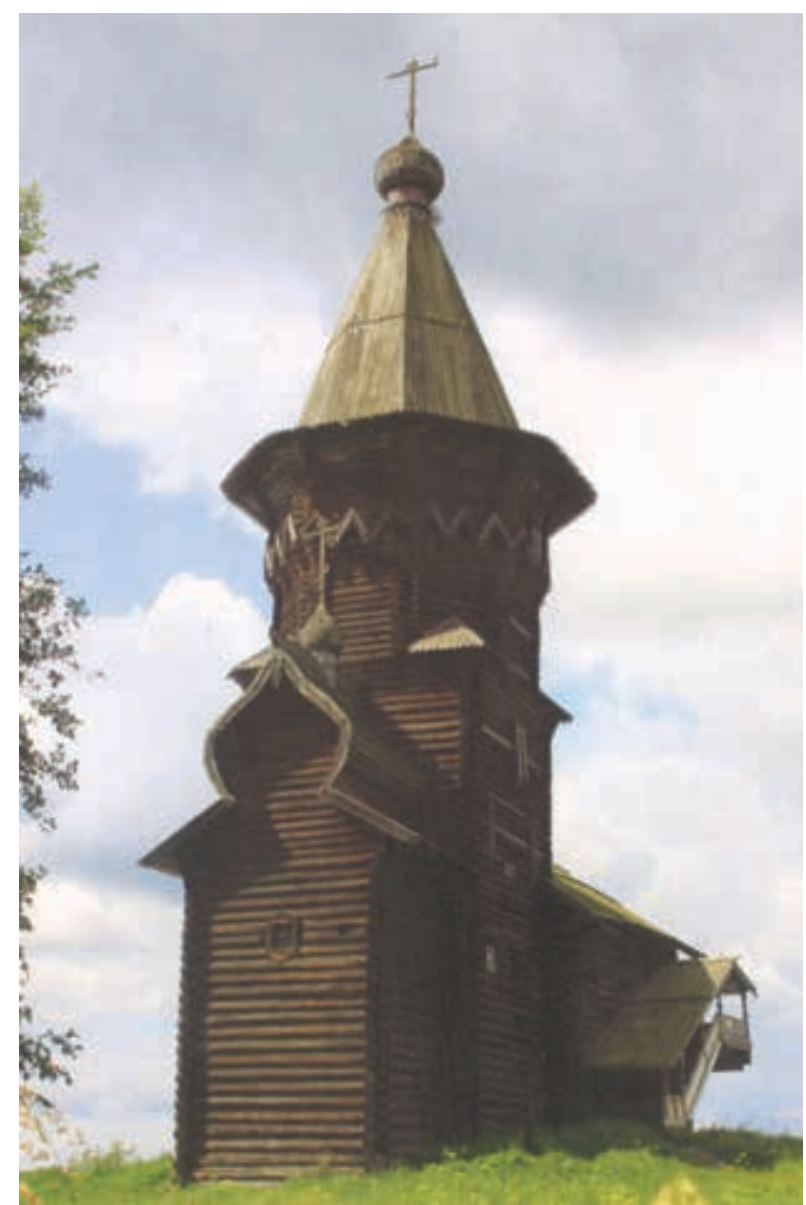

IIl. 12. Kondopoga, Church of the Assumption, dated 1774 (Happykg, Wikimedia Commons)

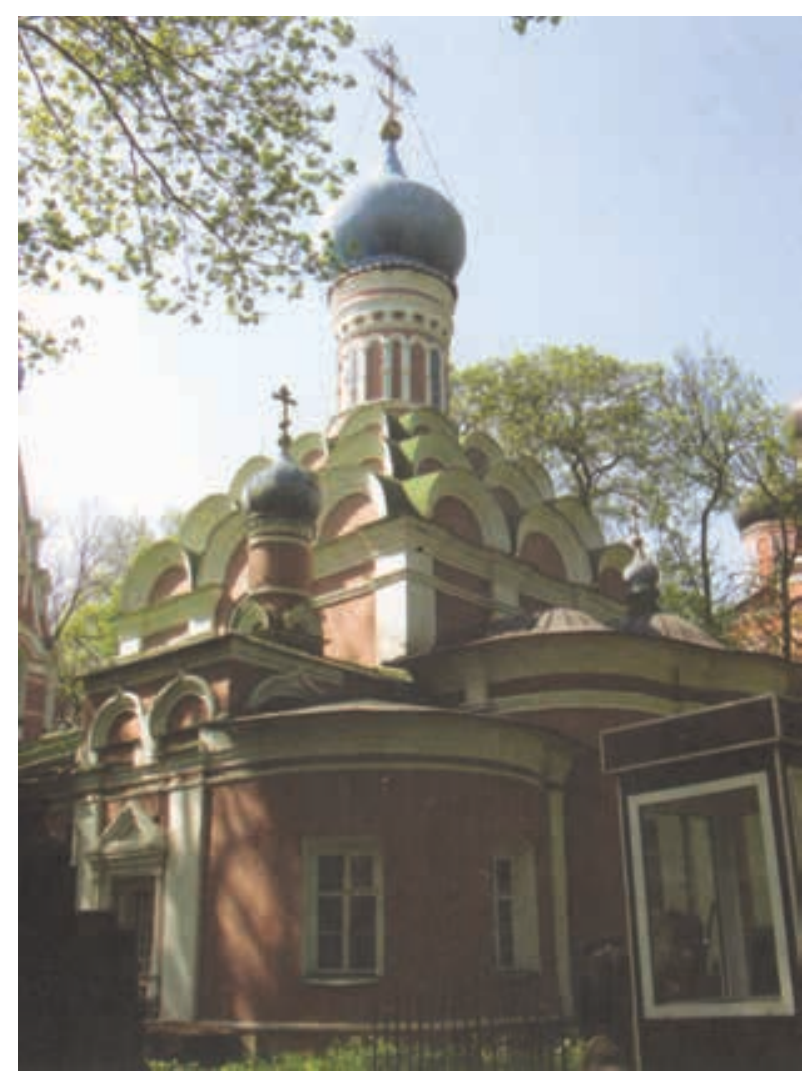

Ill. 14. Moscow, Donskoy Monastery, Old Cathedral, view (author)

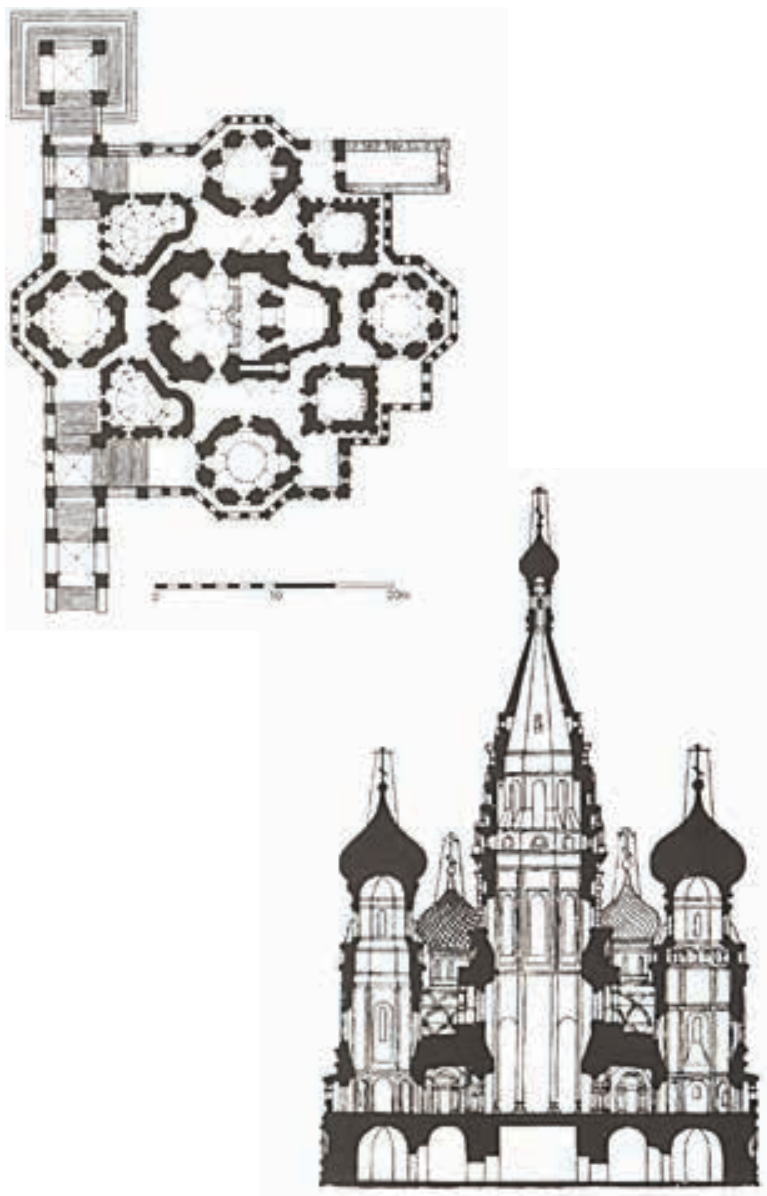

III. 13. Moscow, Cathedral of St. Basil the Blessed (Virgin of the Intercession), plan and transverse section (after H. Faensen and V. Ivanov, Early Russian Architecture, 1975)
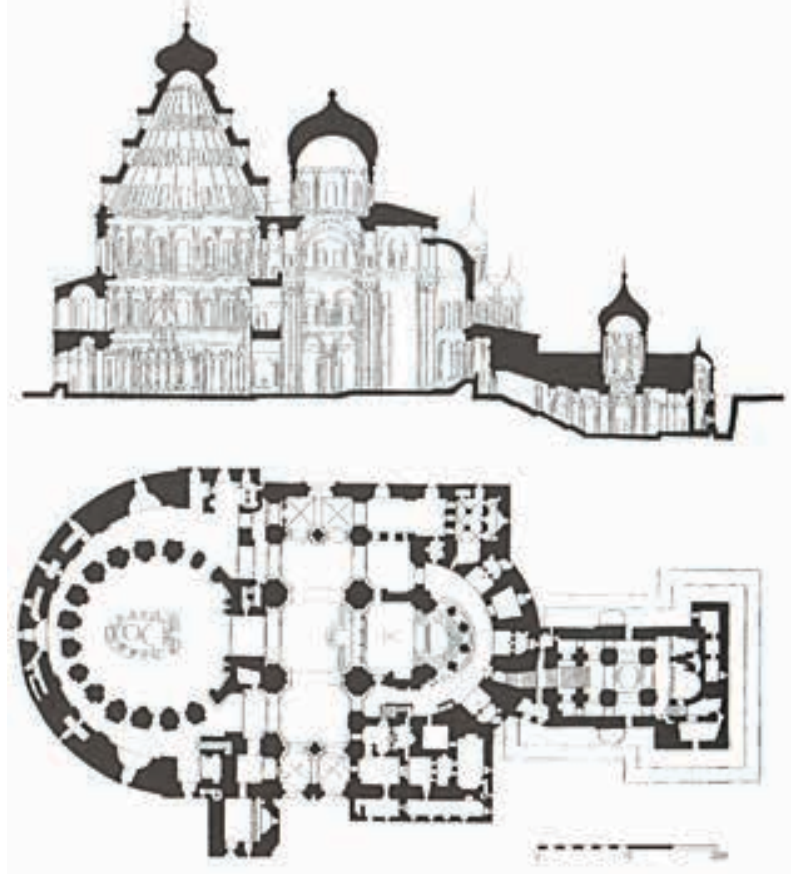

III. 15. Istra, Monastery of the New Jerusalem, Cathedral of the Resurrection, plan and section (after H. Faensen and V. Ivanov, Early Russian Architecture, 1975) 


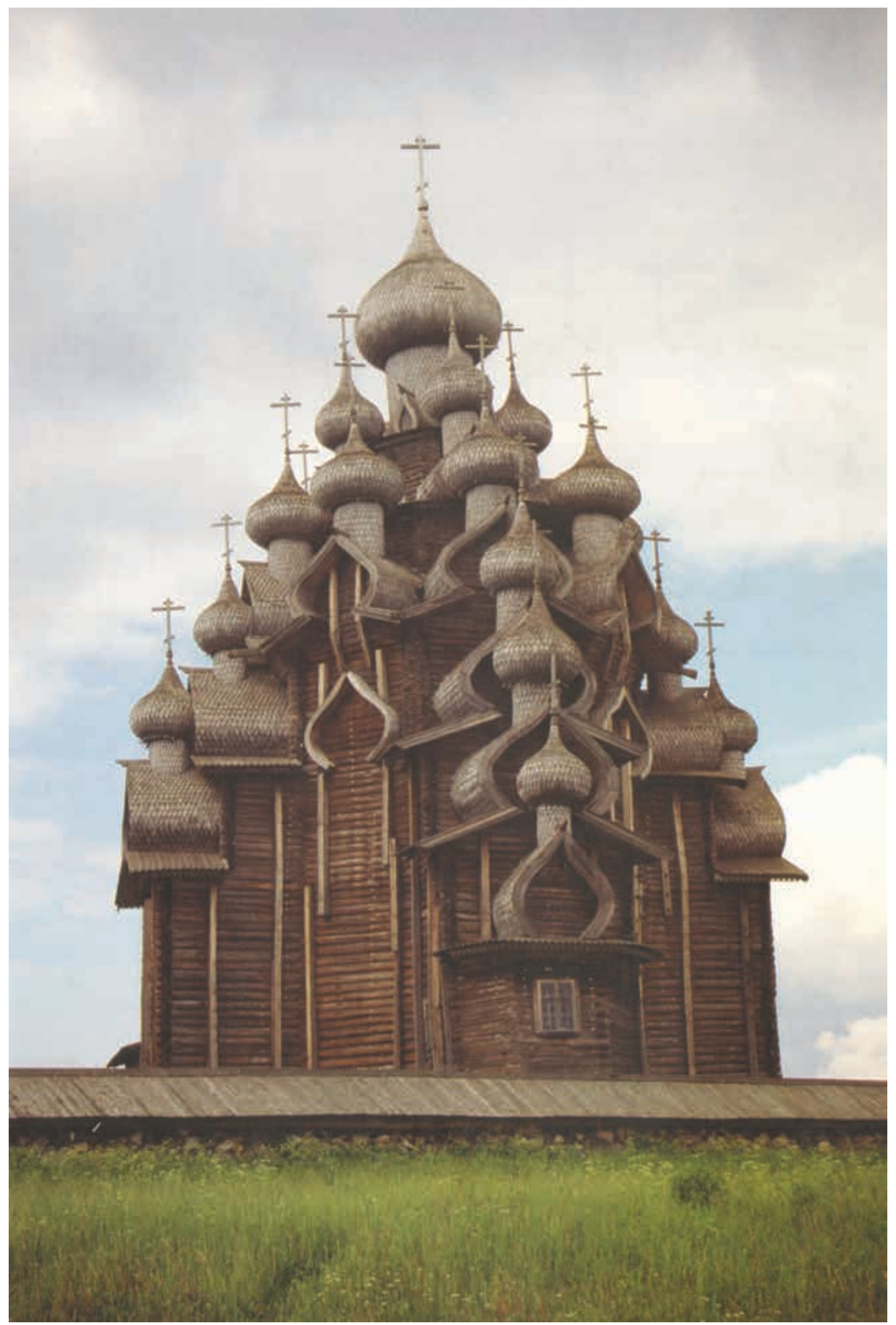

IIl. 16. Lake Onega, Kizhi Island, Church of the Transfiguration, view from the south (J. Stubbs, courtesy World Monuments Fund) 


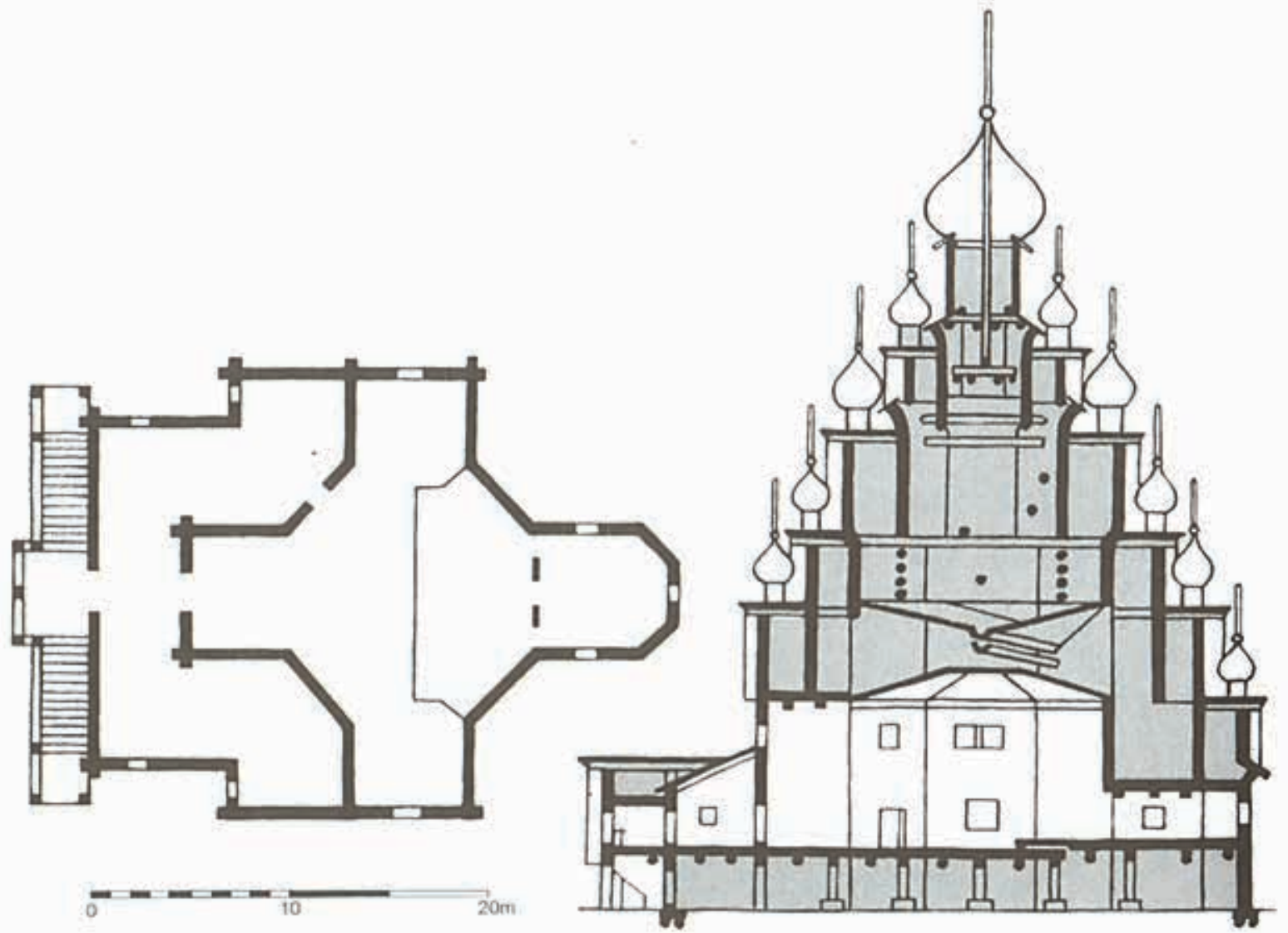

IIl. 17. Lake Onega, Kizhi Island, Church of the Transfiguration, plan and section (after H. Faensen and V. Ivanov, Early Russian Architecture, 1975, with the authors modifications)

With the majority of the Russian churches, the exterior was elaborated while the interior remained relatively simple, as necessitated by Orthodox ritual. An extreme example of this tendency may be seen in the Church of the Transfiguration on Kizhi Island (Lake Onega), built in 1714 and one of the oldest surviving wooden churches (Figs. 16 and 17) ${ }^{9}$. Here the exterior is dominated by the repetition of domes and kokohsniki, all of wood and roofed with shingles. While indicative of the preoccupation with decorative forms, the connection with the interior has been completely lost: the twenty-two domes are simply attachments to the superstructure. The interior is a simple octagon extended with cross arms, covered by a flat ceiling, barely one third the total height, with the sanctuary visually blocked by an iconostasis that extends to the ceiling. In short, the church represents a complete departure from the original Byzantine concept: at the core is the dome, whose meaning as a signifier of sacred space might be similar, but its formal and architectural significance has been lost.

9. Faensen and Ivanov, Early Russian Architecture, 505-11.

\section{REFERENCES}

1. Callmer, J. 1987, "The Archaeology of Kiev to the End of the Earliest Urban Phase", Harvard Ukranian Studies II, pp. 323-64. (in English)

2. Komech, A. I. 1995. Drevnerusskoe zodchestvo konca Xnachala XI v., Moscow.

3. Ioannissian, O., Ivakin, G. 2009. "Desjatinnaja cerkov' v Kieve: 'staryi vzgljad' v novom osveshhenii", Archeologia Abrabamica, Moscow, pp. 179-202. (in Ukrainian)
4. Ivakin, G., Ioannissian, O. \& Jolshin, D. 2013. "Arhitekturno-arheologichni doslidzhennjacerkvi Bogorodici Desjatinnoiv Kievi u 2008-2011." Slovjani I Rus': arheologija ta istorija, pp. 73-80.

5. Shvidkovsky, D. O. 2007. Russian Architecture and the West (New Hüvca 2007) (in English) 


\section{ВОСТОЧНАЯ СРЕДНЕВЕКОВАЯ АРХИТЕКТУРА. РОССИЯ}

В этом номере журнала публикуется продолжение перевода новой книги выдающегося историка архитектуры Византии профессора Пенн юниверсити (США) и почетного профессора Московского архитектурного института (Государственной академии) Роберта Остерхаута «Архитектура Восточного Средневековья. Строительные традиции Византии и близлежащих земель» (Оксфорд Юниверсити Пресс, 2019). Данная часть книги ученого посвящена развитию византийской традиции в русской постренессансной архитектуре. Описание научной биографии Роберта Остерхаута и его вклада в изучение истории зодчества было приведено в опубликованной в предыдущем номере нашего журнала в статье Дмитрия Швидковского «Византия и Остерхаут».

Аннотация. Невозможно переоценить роль профессора Роберта Остерхаута в изучении истории Византийского искусства. Он, безусловно, является сегодня лидером исследований архитектуры Византии в современной мировой науке, подлинным наследником великих Ричарда Краутхаймераи Слободана Чурчича, которых он превзошел в своих исследованиях. Его труды очень хорошо известны в России.

В своём исследовании русской архитектуры средних веков автор анализирует не только художественный образ, но и конструктивные особенности храмового зодчества. Автор выделяет отличительные особенности наиболее крупных центров Москвы, Новгорода, Пскова, Чернигова и др. Большое внимание в статье уделено влияниям итальянской архитектуры на развитие русского храмового строительства, что связано с участием итальянских архитекторов в возведении главных храмов Москвы. Особенно подробно рассмотрены выдающиеся соборы Московского Кремля - Успенский, Благовещенский, Архангела Михаила, созданные при участии итальянских архитекторов.

Русская история и русская архитектура стали развиваться по другому направлению. В XIII веке большая часть Руси, за исключением Новгорода и Пскова, где средневековые церкви сохранились с XII века, была дестабилизирована из-за вторжения монголов. Церкви в Новгороде подобные церкви Феодора Стратилата (1360 г.) или церкви Спаса Преображения на Ильине улице (1374 г.)
Наиболее выдающимся сооружением этого периода автор считает Собор Василия Блаженного, который был построен Иваном IV (Грозным) в память о его победе под Казанью в 1552 году. Храм отличается уникальной композицией. Его составляют девяти примыкающих друг к другу часовен.

В своём исследовании автор также освещает один из нерешенных вопросов развития русской архитектуры появление характерного луковичного купола. Одно из предположений, выдвинутых автором - купола отражают форму навеса над Гробом Христа. Другая гипотеза автора - влияние исламских форм, привнесенных в русскую архитектуру после триумфальной победы русских войск в Казанской битве, которая принесла значительные территории Монголии под контроль России. Автор не может выделить приоритетную версию, но справедливо считает, что каким бы ни было первоначальное значение купольных форм в русской архитектуре, они быстро стали популярными и приобрели собственную символику.

Ключевые слова: Русская архитектура, Восточная средневековая архитектура, история архитектуры.

имеют простые девятичастные планы с лопатками на фасадах и крутыми скатными крышами, восходящими к единой главе. (рис. 1) ${ }^{1}$. Отличительной особенностью является использование

1. По русской архитектуре см. H. Faensen and V. Ivanov, Early Russian Architecture (Лондон, 1975); Brumfield, A History of Russian Architecture; дополнения Shvidkovsky, Russian Architecture. 
лучковых арок на боковых частях фасада, как это было ранее сделано в Пятницкой церкви в Чернигове (см. рис. 12). В новгородских церквях количество лучковых арок увеличено для большего декоративного эффекта. Как и большинство поздних построек в этих местах, они построены в грубоватой манере, фасады оштукатурены.

По мере того, как Русь оправлялась от монгольских нашествий, в Московии образовалась собственная самобытная архитектура, которую впервые можно заметить в соборах Звенигорода под Москвой, посвященных Успению (ок. 13961398 гг., в настоящее время значительно изменен) и Рождеству Богородицы в Саввино-Сторожевском монастыре (ок. 1405-8) (рис. 2). [Примечание: в отличие от Византии, где только одна церковь в районе или городе имела значение собора, в России этот ранг могли иметь несколько церквей в одном районе.] Обе церкви имеют простые девятичастные планы с центральным куполом. Это обычный тип плана соборов, применявшийся по всей Руси, заимствованный из Византийской крестово-купольной системы. Во многих отношениях звенигородские церкви (и их ныне утерянные аналоги в Москве) восходят к моделям церквей во Владимире до монгольского завоевания с вытянутыми вверх пропорциями, построенные из белого известняка. Декоративные арки - закомары, возвышающиеся над пилястрами или аркатурно-колончатыми поясами, венчают фасадные пролеты. Декоративные скульптурные пояса оживляют фасады, порталы имеют ступенчатое обрамление и архивольты со стрельчатыми арками. Закомары Успенской церкви должно быть тоже имели стрельчатые арки, такие же, как те, которые сохранились на Рождественской церкви. В дополнение к тем закомарам, что на фасаде, имеется второй ярус, расположенный по диагонали над углами, и третий ярус, обрамляющий барабан купола. Декоративность закомар усиливается ослаблением взаимоотношений между интерьером и экстерьером, поскольку пилястры не всегда соответствуют структурным частям интерьера. Эти детали, использованные в старейшем сохранившемся московском храме - Спасском соборе Андроникова монастыря, построенном в 1420-х годах, увеличивают сложность пояса декоративных арок, постепенно поднимающегося к основанию купола.

Начало истории Москвы обычно относят к её первому упоминанию в текстах 1147 года, хотя поселение должно быть образовалось гораздо раньше. В 1156 году деревянная крепость стояла на возвышенности у слияния Москвы и меньшей реки Неглинной, где сейчас стоит Кремль (рис. 3 и 4). Название Кремль означает «цитадель», но, как и Акрополь в Афинах, оно стало топонимом конкретной местности. Ранняя история Москвы характеризуется столкновениями с монголами и враждующими русскими княжествами. В начале своей истории Москва была немногим больше, чем торговым форпостом в обширных лесах Руси. K XIV веку город становится важным центром, особенно при Иване I, который пришёл к власти в 1325 году. В этом же году патриарх Петр выбрал Москву в качестве своей неофициальной резиденции, что положило начало консолидации церкви и государства. Вскоре после этого был построен первый каменный храм - Успенский собор (впоследствии перестроенный), который унаследовал значение Владимирского собора как духовного центра России. Продолжающиеся столкновения с монголами, вынудили в 1367 году перестроить укрепления в белом камне более или менее в соответствии с линиями нынешнего треугольного ограждения, протяженностью около 2 км. Внешний вид Кремля и города вокруг него трудно представить до XV века поскольку традиционная русская архитектура была эфемерной, построенной из дерева и подверженной пожарам.

K концу XV века вместе с приглашенными итальянскими архитекторами возникли новые архитектурные веяния. Период правления Ивана III (1462-1505) особенно важен. За ним следует период правления его сына Василия III (1505-33). В 1472 году Иван женился на Зое (переименованной в Софию) Палеолог, племяннице последнего византийского императора и претендентки на византийский престол ${ }^{2}$. После падения Византийской империи она бежала к папскому двору в Риме, где она попала под защиту кардинала Виссариона, который впоследствии устроил ее брак с Иваном. Через Виссариона София была связана с греческими и итальянскими интеллектуальными кругами северной Италии и, таким образом, привезла с собой в Москву итальянский ренессанс и византийские веяния. Вскоре после этого итальянские архитекторы заняли видное место в русской истории ${ }^{3}$.

2. A.M. Talbot, Sophia Palaiologina, Oxford Dictionary of Byzantium, том 3. (Оксфорд, 1991), 1928.

3. Shvidkovsky, Russian Architecture, стр.73-104. 
Первым крупным проектом была перестройка Успенского собора в Кремле в 1475-79 гг. под руководством Ридольфо Аристотеля Фиораванти (рис. 5-7). Реконструкция первоначальной церкви была предпринята московскими строителями в 1472 году, но через два года она рухнула, когда уже приближалась к завершению. Консультировались с зодчими из Пскова, но они отказались браться за проект, что вынудило Ивана обратиться к экспертам из других стран. Болонский архитектор Фиораванти был хорошо известен в Италии своими инженерными навыками и дружил с теоретиком Филарете. По прибытии в Россию его отвезли во Владимир, чтобы осмотреть Успенский собор, которому его проект был призван подражать и превзойти (см. рис. 8 и 9). Таким образом, он объединил романские детали, заимствованные из Владимира, с упрощенным двенадцатичастным планом, увенчанный пятью куполами. Фиораванти применил модульный план, по которому все части имели одинаковые размеры, а возвышающиеся над цилиндрическими опорами своды были расположены на одной высоте и перекрывали части без купола.

Чтобы сохранить модульную схему, соединенные часовни по бокам святилища были перекрыты одним куполом. Чтобы придать ему значимость, купол увеличили в масштабе - его диаметр стал больше, чем ширина пролёта, который он покрывает. Вместо отдельного притвора, три западных отсека, все сводчатые, полностью интегрированы в модульную конструкцию. На фасадах детали упрощены; закомары сделаны одинаковыми, части фасада разделены пилястрами, а романские формы порталов и фриз карниза напоминают Владимирский собор. Фиораванти использовал тщательно вырезанный известняк, кладка была закреплена прочным раствором, а свод сооружен из легкого кирпича, укрепленного железными стяжками.

Интерьер напоминает просторный зал, который легко было приспособить для императорских церемоний, так как собор должен был стать коронационной церковью. В последующие века постепенное увеличение иконостаса стало закрывать вид на восточные своды. Хотя иконостас органично сочетается с настенной росписью, он меняет пространственную конфигурацию таким образом, что центральный купол больше не воспринимается в центре, а только как окончание продольной оси наоса с невидимым святилищем за иконостасом. Собор представляет собой тра- диционный русско-византийский архитектурный словарь, переосмысленный итальянским архитектором эпохи Возрождения.

Параллельно с появлением архитектурных идей эпохи Возрождения внедрялись византийские придворные церемонии и идеологии, которые скорее всего пришли с Софьей Палеолог. Иван провозгласил детей от Софии своими наследниками, а не детей от своей первой жены, тем самым застраховав византийскую родословную. В течение нескольких десятилетий мы начинаем находить упоминания о Москве как о «Третьем Риме» и «Втором Константинополе», поскольку Русь взяла на себя роль политического и духовного преемника Византии как оплота православия. С придворным церемониалом появились и придворные титулы; Иван III начал использовать титулы царь (производное от Цезаря) и император.

В 1484-89 гг, Вскоре после завершения строительства Успенского собора, был перестроен соседний Благовещенский собор с целью сделать его дворцовой часовней (рис. 8 и 9). Работы выполняли псковские архитекторы, ранее отказавшиеся взяться за восстановление Успенского собора после его обрушения. Церковь вышла значительно меньше и проще; по сути, это была девятичастная церковь с колоннами, установленными на сводчатой структуре, чтобы довести ее до уровня жилых комнат в соседнем дворце к западу от нее. Первоначально она была увенчана тремя куполами, с еще двумя небольшими куполами над часовнями, обрамляющими святилище. Её силуэт был усилен наложенными фронтонами (кокошниками) со стрельчатыми арками. В следующем столетии он был расширен, с крытой террасой, образующей передвижную, увенчанную независимыми купольными часовнями на уровне галереи (1562-64), с двумя новыми куполами, добавленными над западными углами наоса. По сравнению с Успенской церковью, интерьер этого собора относительно тесный, ограниченный знаменитым иконостасом (расписанный Феофаном Греком, Прохором Городецким и Андреем Рублевым), который закрывает святилище и прилегающие к нему часовни. Несмотря на свой статус кафедрального собора, церковь функционировала как частная часовня для молитв членов царской семьи. Особенный по стилю, Благовещенский собор представляет собой продолжение традиционных архитектурных форм, одновременно с новыми веяниями эпохи Возрождения. 
Собор Архангела Михаила в Кремле, построенный около 1505-1509 гг. по проекту венецианского архитектора Алевизе Ламберти да Монтаньяна, продолжил традицию Возрождения, начатую Фиораванти (см. рис. 4). Пятиглавая структура собора повторяет устройство Успенского собора, хотя он был построен меньше по размеру. Его элегантный внешний вид выполнен в классическом стиле, с коринфскими капителями на пилястрах и орнаментальными раковинами в закомарах. Точно так же колокольня Ивана Великого была начата миланским архитектором, известным как Бон Фрязин (1505-8). Её нижние части напоминали отдельно стоящую колокольню в ломбардском стиле, хотя впоследствии она была увеличена и расширена, чтобы вместить двадцать один колокол (см. рис. 4).

Начиная с 1485 г. Кремль укрепляется новыми стенами из красного кирпича по линии старых каменных стен с выступающими башнями (рис. 10). Работа была возложена на российских и итальянских строителей, которые руководили строительством башен. После возведения укреплений жилого квартала Китай-город к востоку от Кремля (1536-39) планировка Москвы стала напоминать Смедерево в Сербии - с цитаделью в стратегической точке большого треугольного ограждения, отделенного от жилого района рвом. В то же время башни отражали тенденции итальянского Возрождения того времени, особенно ломбардской архитектуры. Если не считать более поздние декоративные пристройки, стены Кремля не выглядели бы неуместными в Милане.

В Коломенском, когда-то царской усадьбе над Москвой-рекой, сохранилось несколько церквей, самая важная из которых - церковь Вознесения, построенная после 1528 года в память о рождении Ивана IV и освященная в 1532 году (рис. 11). План беспрецедентный: квадратный наос, расширенный крестообразными выступами, установлен на возвышении. По мере того, как церковь поднимается, верхняя ступень становится восьмиугольной, покрытой пирамидальной крышей шатра, все построено из кирпича. Кокошники появляются на переходе к восьмиграннику, с закомарами у основания крутой скатной крыши. Впервые увиденная здесь шатровая крыша стала заметной особенностью архитектуры эпохи царя Ивана, но ее происхождение неясно. Одна из теорий гласит, что шатровая крыша появилась из местной деревянной архитектуры, хотя образцы этого раннего периода не сохранились (сравните рис. 12) ${ }^{4}$. Следуя этой линии, новые архитектурные формы, представленные в Коломенском, резко контрастируют с итальянскими соборами Кремля и, таким образом, могли бы обозначить консервативную, националистическую реакцию против иностранного влияния.

Недавние исследования выявили детали в стиле итальянского Возрождения (и даже готические) в церкви Вознесения, и документальные свидетельства теперь указывают на то, что за ее дизайн отвечал итальянский архитектор Пьетро Аннибале, известный на Руси как Петрок Малый, тот же архитектор, который руководил строительством стен Китай-города ${ }^{5}$. Для создания 62-метрового здания, для чего требовался фундамент глубиной 9 метров, нужен был квалифицированный инженер. Тем не менее, архитектор, безусловно, осознавал визуальное воздействие традиционных русских форм, о чем свидетельствует применение кокошников и закомар. Следует ли нам отнести шатровую крышу в эту же категорию? Как бы то ни было, похоже, что итальянский архитектор был ответственен за введение определенных форм каменной кладки, тех, которые позже стали интерпретироваться как исконно русские.

Самая знаковая из московских церквей также является самой необычной. Собор Василия Блаженного был построен Иваном IV (Грозным) в память о его победе под Казанью в 1552 году решающем событии в русской истории; строительство церкви было завершено в 1561 году (рис. 13) ${ }^{6}$. Первоначально он был посвящен Покрову Богородицы, но постепенно стал ассоциироваться с Василием Блаженным, юродивым, погребальная часовня которого была пристроена в конце XVI века. Изначально церковь фактически состояла из девяти примыкающих друг к другу часовен, возведенных на возвышении. Восемь часовен по периметру поднимаются на разную высоту и живописно увенчаны своеобразными луковичными куполами. Центральная часовня Богородицы возвышается над остальными и покрыта шатром, увенчанным небольшим позолоченным луковичным куполом. Внутренние помещения высокие и напоминают башни, с максимальным визуальным эффектом, направленным на экстерьер. Луковичные купола на самом

4. Faensen and Ivanov, Early Russian Architecture, стр.437-39.

5. Shvidkovsky, Russian Architecture, стр.111-21.

6. Shvidkovsky, Russian Architecture, стр.126-40. 
деле полые, образованы металлическим покрытием по арматуре; внутри часовня заканчивается довольно скромными сомкнутыми сводами.

Собор Василия Блаженного во многом напоминает декорации, и он соответствующим образом стал фоном для гражданских и религиозных церемоний, посредством которых Москва символически выражала свою идентичность. Главная западная часовня была посвящена Входу Христа в Иерусалим, что стало предметом особой церемонии в Вербное воскресенье: патриарх, проводимый царем, ехал на осле во главе процессии, торжественно воссоздавая вхождение Христа в Иерусалим. Благодаря таким церемониям церковь, а впоследствии и Москва стали ассоциироваться с Иерусалимом.

Один из нерешенных вопросов развития русской архитектуры - появление характерного луковичного купола: имеет ли он особое значение или функцию? Большинство только что обсуждавшихся церквей было построено без них, но они были добавлены в ходе более поздних перестроек. Те, которые находится на соборе Василия Блаженного, несомненно, являются неотъемлемой частью его создания.

Одно из предположений - они функциональны и отводят снег с крыши. Другая гипотеза они отражают форму навеса над Гробом Христа. Возможно, наиболее убедительным предположением является признание исламских форм, принятых в качестве триумфального мотива после Казанской битвы, которая принесла значительные территории Монголии под контроль России 7 . Каким бы ни было первоначальное значение этих куполов, они быстро стали популярными и приобрели собственную символику; их форму сравнивали с пламенем свечи, являющимся маяком Православия.

Не все церкви в Москве похожи на храм Василия Блаженного. Ренессансное переосмысление византийских форм в Успенском соборе нашло заметных последователей, как, например, это видно в Успенском соборе в Троице-Сергиевой Лавре в Сергиевом Посаде (1559-85 гг.), почти точно копирующим его тезку, включая модульный, двенадцатичастный план с пятью куполами и пятью апсидами. Построенное при Иване IV повторение первоначального собора, было предназначено

7. Shvidkovsky, Russian Architecture, стр.128, с примечаниями к работам Брунова, Ильина, Баталова, Вячаниной, Бондаренко. для обозначения власти и связи монастыря с царской семей. Построенный почти одновременно с храмом Василия Блаженного и имеющий одного и того же покровителя, храм отражает стилистическое разнообразие, возможное в русской архитектуре. Другая стилистическая вариация видна в Донском монастыре, основанном в 1591 году на месте отражения нападения татар будущим царём Борисом Годуновым с помощью чудотворной иконы Донской Богородицы (рис. 14). Старый собор, построенный в 1591-93 годах, относительно прост в плане, но его крыша состоит из ряда закомар, поставленных пирамидально и завершающихся луковичным куполом, над высоким барабаном. Как и во многих других примерах впечатляющий внешний вид контрастирует с относительно консервативным интерьером.

Дань России средиземноморью также очевидна в монастыре Новый Иерусалим в Истре под Москвой, основанном в 1656 году патриархом Никоном (рис. 15) ${ }^{8}$. Увеличенная копия Храма Гроба Господня в Иерусалиме, созданная в характерном для России стиле, оказывается значительно более зрелищной, чем его прототип. В то же время монастырь тщательно повторяет строение Иерусалима, основываясь на планах и моделях. Построенный в том же масштабе в плане, что и оригинал, он был значительно выше, с шатром, возвышающимся над ротондой на высоту более 60 метров. Современники Никона, которого в свое время критиковали за самонадеянность, рассматривали здание как оскорбление священного, а не как его осмысление.

В большинстве русских церквей внешний вид был тщательно продуман, а интерьер оставался относительно простым, как того требует православный ритуал. Ярким примером этой тенденции является церковь Преображения Господня на острове Кижи (Онежское озеро), 1714 года постройки, одна из старейших сохранившихся деревянных церквей, (рис. 16 и 17) ${ }^{9}$. Здесь во внешнем виде преобладает повторение деревянных куполов и кокошников, покрытых деревянной черепицей. Хотя это свидетельствует об увлечении декоративными формами, связь с интерьером полностью утрачена: двадцать два купола являются просто креплениями к надстройке.

8. Shvidkovsky, Russian Architecture, стр.169-73; R. G. Ousterhout, Building the New Jerusalem, B Jerozolima w kulturze europejskiy, ред. P. Paszkiewicza и Т. Zadroznego (Варшава, 1997), стр.143-54.

9. Faensen and Ivanov, Early Russian Architecture, стр. 505-11. 
Интерьер представляет собой простой восьмиугольник расширенный по форме креста, перекрытый плоским потолком на уровне трети от общей высоты, со святилищем, визуально закрытым иконостасом, доходящим до потолка. Церковь представляет собой полный отход от первона- чальной византийской концепции: в основе лежит купол, значение которого как обозначение священного пространства может быть аналогичным, но его формальное и архитектурное значение потеряно.

\section{БИБЛИОГРАФИЯ}

1. Callmer, J. 1987, «The Archaeology of Kiev to the End of the Earliest Urban Phase», Harvard Ukranian Studies II, pp. 323-64.

2. Комеч, А.И. Древнерусское зодчество конца X начала XII в. - М.: Наука, 1987. - 320 с.

3. Иоаннисян О., Ивакин Г. 2009. Десятинная церковь в Киеве: старый взгляд нового освещения // Archeologia Abrabamica, Москва, С. 179-202.
4. Ивакин, Г., Иоаннисян, О., Джолшин, Д. 2013. Архітектурно-археологічні дослідження десятинної церкви 2008-2009 pp. // Slovjani I Rus': arheologija ta istorija, C. $73-80$.

5. Швидковский Д. 2007. Российская архитектура и Запад (New Hüvca) 